\title{
Thrixspermum japonicum (Miq.) Rchb.f. [Orchidaceae: Epidendroideae: Vandeae: Aeridinae] - an addition to the Orchid flora of India
}

\author{
Khyanjeet Gogoi ${ }^{1}$ and Koj Rinya ${ }^{2}$ \\ ${ }^{1}$ Communicating author: TOSEHIM, Regional Orchids Germplasm Conservation \& Propagation Centre \\ (Assam Circle), Daisa Bordoloi Nagar, Talap, Tinsukia 786 156, Assam, India, \\ E-mail:khyanjeetgogoi@gmail.com \\ ${ }^{2}$ Divisional Forest Officer, Hapoli Forest Division, Lower Subansiri District, \\ Arunachal Pradesh, India, E-mail: dfohapoli@gmail.com
}

[Received 18.11.2019; Revised \& accepted 20.12.2019; Published 31.12.2019]

\begin{abstract}
Thrixspermum japonicum (Miq.) Rchb.f. of Orchidaceae is reported as an addition to the orchid flora of India from the Ziro Valley of Arunachal Pradesh. A detailed description along with a plate of illustrations of the species is provided in the paper.
\end{abstract}

Key words: Thrixspermum japonicum, Orchidaceae, new record, India.

\section{INTRODUCTION}

During a field trip under Orchid translocation project, to the forested area of Ziro valley of lower Subansiri district of Arunachal Pradesh on 12 December, 2018, the senior author collected an interesting epiphytic orchid in its vegetative condition. It was brought under cultivation at the orchid trail located in the Talle wildlife Sanctuary, Ziro valley of Arunachal Pradesh where it flowered under observation in October, 2019. On the basis of available literature (King \& Pantling 1898; Pradhan 1979; Chowdhery 1998; Pearce \& Cribb 2002; Lucksom 2007; Chen et al. 2009; Rao 2009, 2010; Mao et al. 2011; Gogoi 2018, 2019) and critical examination of the flowers, it was identified as Thrixspermum japonicum (Miq.) Rchb.f. that has earlier been known from southern Japan, Korea, China, Bhutan and Taiwan but was never before reported from the India. Hence, a detailed description, illustration, information on habitat and distribution has been provided in the present paper. The voucher specimen of the taxon has been deposited in ASSAM Herbarium of the Botanical Survey of India at Shillong and Herbarium of The Orchid Society of Eastern Himalaya (TOSEHIM), Regional Orchid Germplasm Conservation and Propagation Centre (Assam Circle), Assam.

Thrixspermum Lour. is one of the larger monopodial orchid genera with about 100 species distributed widely from the Himalayas to Philippines and tropical Islands of S.W. Pacific (Chen et al. 2009). So far, 11 species has been reported from India (Misra 2007) and 4 species from Arunachal Pradesh viz. Thrixspermum centipede Lour., T. musciflorum Rao \& Joseph, T. saruwatarii (Hayata) Schltr. and T. changlangensis Gogoi ( Rao 2009 ; Mao et al. 2011; Hegde 2017; Gogoi 2019). With the present report of Thrixspermum japonicum (Miq.) Rchb.f. from the Ziro Valley, forms a new addition to India and also to Arunachal Pradesh, thereby making the total number of Thrixspermum species eleven in India and five in Arunachal Pradesh. 


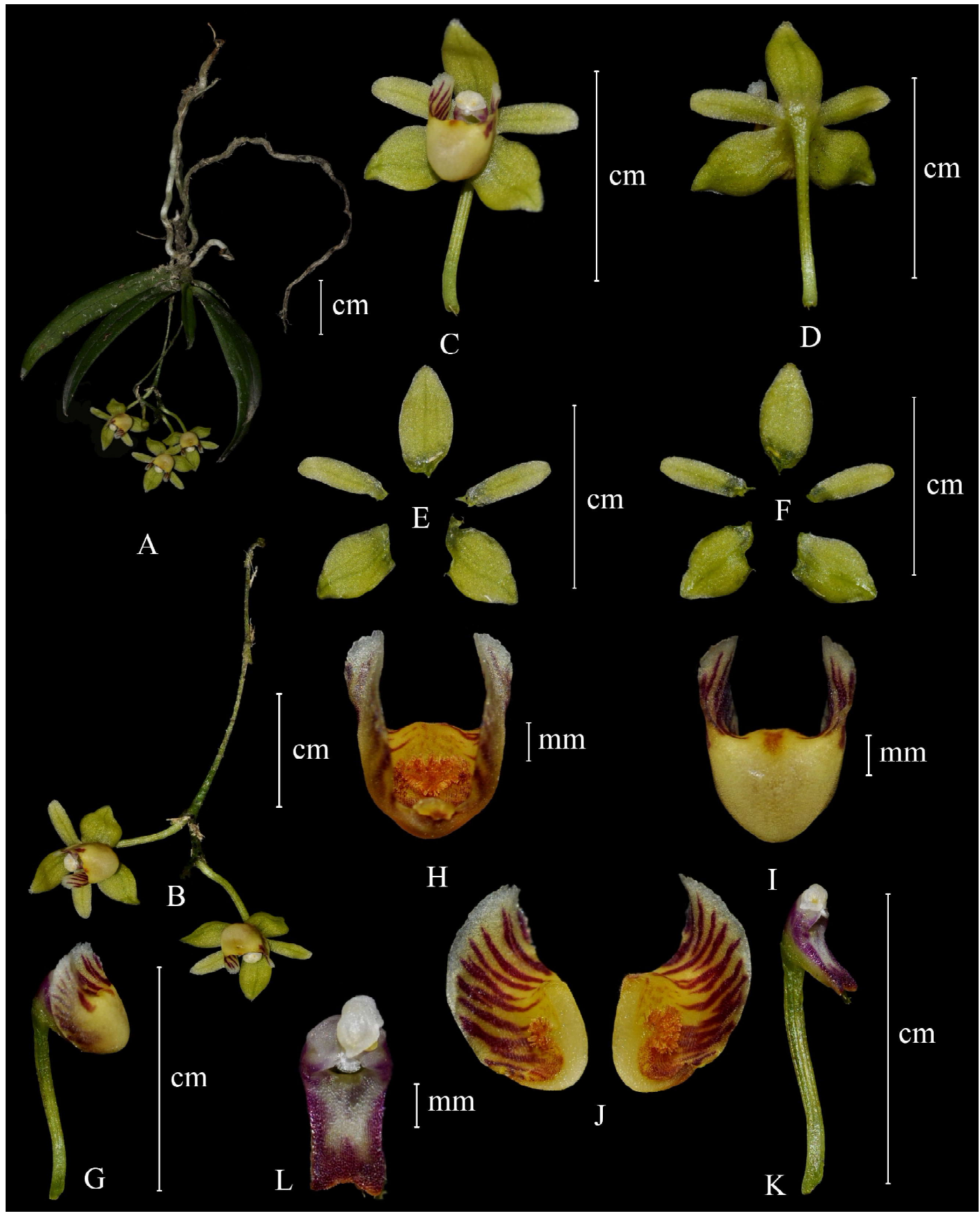

PLATE - I. Thrixspermum japonicum (Miq.) Rchb.f. : A. Whole plant habit; B. Inflorescence; C \& D. Different views of flower; E \& F. Perigone, ventral and dorsal views; G. Lip with ovary and column; H \& I. Lip; J. Longitudinal section of lip; K. Pedicel, ovary and column; L. Column. 
Thrixspermum japonicum(Miq.) Rchb.f., Bot. Zeitung (Berlin) 36: 75. 1878.

Sarcochilus japonicus Miq., Ann. Mus. Bot. Lugduno-Batavi 2: 206. 1866. [Plate - 1]

Plants $2-10 \mathrm{~cm}$ with leaves, slender, with densely many leaved. Leaves purplish green, narrowly oblong or oblanceolate, $2-4 \times 0.5-0.7 \mathrm{~cm}$, leathery, oblong to oblanceolate, bilobed at apex. Inflorescences often 2 to many, opposite to leaves, $3-5 \mathrm{~cm}$, laxly $3-$ 4 flowered. Flowers creamy yellow; lip yellow with white margins, heavily marked with reddish brown stripes. Pedicel and ovary $0.6 \mathrm{~cm}$. Dorsal sepal oblong, $0.5-0.7 \times 0.2-$ $0.3 \mathrm{~cm}$, obtuse; lateral sepals ovate-lanceolate, $0.5-0.7 \times 0.3-0.4 \mathrm{~cm}$, obtuse. Petals narrowly oblong, $0.5-0.6 \times 0.2 \mathrm{~cm}$, obtuse; Lip 3-lobed, base with a claw $0.1 \mathrm{~cm}$; lateral lobes sub-erect, falcate, narrowly sub-oblong, $0.3 \times 0.1 \mathrm{~cm}$, obtuse-rounded; mid-lobe sub-orbicular, $0.1 \mathrm{~cm}$ wide, fleshy, abaxially conic-swollen; disk slightly concave at base, densely hairy.Column $0.2-0.3 \mathrm{~cm}$ with a foot. Pollinia 4. Capsules elongate and thin, $2-3 \mathrm{~cm}$.

Specimen Cited: India, Arunachal Pradesh, Ziro Valley, Gogoi - 00804, 12 October 2019 [ASSAM, TOSEHIM Herbaria]

Flowering \& Fruiting: September - October.

Habitat: Epiphytic on trees or branches, growing on the twigs and small branches of Pine trees.

General distribution: Bhutan, India (Ziro, Arunachal Pradesh), China, Korea and southern Japan.

Status: Unknown.

\section{Acknowledgements}

The authors are grateful to Dr. Pankaj Kumar, Kadoorie Farm and Botanic Garden (KFBG) Corporation, Lam Kam Road, Tai Po, New Territories, Hong Kong S.A.R., China for providing literature and valuable suggestion during identity of the species. They are also thankful to the Department of Environment and Forest, Government of Arunachal Pradesh (India) for their cooperation during the entire survey.

\section{LITERATURE CITED}

Chen, X.; Liu, Z.; Zhu, G.; Lang, K.; Ji, Z.; Luo, Y.; Jin, X.; Cribb, P.J.; Wood, J.J.; Gale, S.W.; Ormerod, P.; Vermeulen, J.J.; Wood, H.P.; Clayton, D. \& Bell, A. 2009. Orchidaceae, in: Wu, Z.; Raven, P.H. \& Hong, D. (eds), Flora of China. Vol. 25. Science Press, Beijing; Missouri Botanical Garden Press, St. Louis, USA

Chowdhery, H.J., 1998. Orchid Flora of Arunachal Pradesh. Bishen Singh Mahendra Pal Singh, Dehra Dun, India.

Gogoi, K. 2018. Wild Orchids of Assam - A Pictorial Guide. Assam State Biodiversity Board, Guwahati, Assam.

Gogoi, K. 2019. Thrixspermum changlangensis sp.nov. [Orchidaceae: Epidendroideae: Vandeae: Aeridinae] from Arunachal Pradesh in Northeast India. Pleione 13(1): $167-170$.

King, G. \& Pantling, R. 1898. The orchids of the Sikkim Himalayas. Annals of the Royal Botanical Garden Calcutta 8: 1 - 342.

Lucksom, S.Z., 2007. The Orchids of Sikkim and North East Himalaya: Development Area, Jiwan Thing Marg, Gangtok, East Sikkim, India. 
Mao, A.A.; Rao, A.N.; Bhaumik, M. \& Apang, Ona 2011. Thrixspermum saruwatarii (Hayata) Schltr. (Orchidaceae) - a new record to India from Arunachal Pradesh. Bull. Arunachal For. Res. 27(1\&2): 68 - 70.

Misra, S. 2007. Orchids of India. Bishen Singh Mahendra Pal Singh, Dehra Dun, India.

Pearce, N.R. \& Cribb, P.J. 2002. Orchids of Bhutan: Flora of Bhutan. Vol. 3, No. 3. Royal Botanical Garden, Edinburg.

Pedersen, H.A.E.; Kurzweil, H.; Suddee, S.; Vogel, Ed F.; Cribb, P. J.; Chantanaorrapint, S.; Watthana, S.; Gale, S.W.; Seelanan, T. \&Suwanphakdee, C. 2014. Flora of Thailand, Vol-12, part 2: Prachachon co. ltd., Thailand.

Pradhan, U.C. 1979. Indian Orchids Guide to Identification and Culture. Vol- II. Thomson Prass, Faridabad, India.

Pridgeon, A.M.: Cribb, P.J.; Chase, M.W. \& Rasmussen, F.N. 2009. Genera Orchidacearum, Volume 5: Epidendroideae (Part 2). Oxford University Press, $584 \mathrm{pp}$.

Rao, A.N. 2009. Monopodial orchids of Arunachal Pradesh (India)-Classification, Taxonomy Distribution and Conservation. Bull. Arunachal For. Res. 25 (1\&2): 55 - 92.

Rao, A.N. 2010. Orchid flora of Arunachal Pradesh - an update. Bull. Arunachal For. Res. 26 (1\&2): $82-110$. 